\title{
ESSAY
}

\section{PLENARY POWER PREEMPTION}

\author{
Kerry Abrams ${ }^{*}$
}

\section{INTRODUCTION}

$\mathrm{T}$ HIS Essay responds to the Supreme Court's recent decision in Arizona $v$. United States, which struck down all but one of the disputed sections of Arizona's S.B. 1070 immigration law. It advances the theory that although the Arizona Court purported to apply classic conflict and field preemption analyses, it was actually using a different form of preemption, one that gives particular weight to federal interests where questions of national sovereignty are at stake. The Court did so through doctrinal borrowing of the "plenary power doctrine," which gives the political branches special deference when passing or executing immigration legislation, even where doing so would otherwise violate individual constitutional rights. This Essay labels the form of preemption used in Arizona and other alienage cases "plenary power preemption." It shows how this doctrine developed over time, as the scope of the legitimate exercise of state police power and federal immigration changed, and federal and state regulation of noncitizens became more complex and enmeshed. It argues that plenary power preemption has two important effects: it allows courts to evade the thorny question of the scope of executive-as opposed to legislative-power over immigration, and it substitutes for the lack of an equal protection doctrine that adequately protects unauthorized aliens from discrimination.

In Arizona $v$. United States, the Supreme Court determined whether certain provisions of Arizona's Support Our Law Enforcement and Safe

\footnotetext{
* Albert Clark Tate, Jr., Professor of Law, University of Virginia School of Law. Earlier versions of this paper benefitted greatly from law faculty workshops at the University of Virginia, the University of Iowa, and the University of Baltimore. I especially appreciate comments and suggestions made by Barbara Armacost, Arthur Bonfield, Anne Coughlin, John Duffy, Stella Elias, Ann Laquer Estin, Kim Forde-Mazrui, Brandon Garrett, Michele Gilman, Leigh Goodmark, Paul Gowder, John Harrison, Deborah Hellman, William Hubbard, David Jaros, Liz Keyes, Matthew Lindsay, David Martin, Angela Onwuachi-Willig, Dan Ortiz, Christopher Peters, Colin Starger, Lea Vandervelde, and Rip Verkerke. For their helpful research assistance, I thank Sarah Delaney and Nick Peterson.
} 
Neighborhoods Act, commonly known as S.B. 1070, were preempted by federal law. ${ }^{1}$ Justice Anthony Kennedy's majority opinion, which struck down some portions of the law but withheld judgment on one key provision, has been read by some as a victory for Arizona and by others as a resounding win for the federal government. ${ }^{2}$ Less debated, but equally if not more important, is what the opinion means for preemption doctrine going forward. Numerous other states have anti-immigration statutes on their books, some of which have already been invalidated or upheld in the wake of Arizona. ${ }^{3}$ Lower courts, state legislatures, and activists representing diverse agendas will all be looking to Arizona for guidance on the proper scope of state immigration regulation.

The Arizona opinion, however, may obscure as much as it illuminates. At first glance, it appears to contain a combination of a rhetorically powerful but doctrinally empty reaffirmation of federal power, coupled with field and conflict preemption analyses. After a short opening section describing the procedural posture of the case, Part II of the opinion launches into an ode to federal power. "The Government of the United States has broad, undoubted power over the subject of immigration and the status of aliens," the majority opinion proclaims. ${ }^{4}$ This power, according to the Court, derives from two sources: the textual constitutional grant of the power to "establish an uniform Rule of Naturalization," and "its inherent power as sovereign to control and conduct relations with foreign nations." Only then does the majority go on to strike down most of the disputed sections of Arizona's statute, leaving only one section standing, and preserving even that section in a way that may seriously curtail the State's ability to actually enforce it. ${ }^{6}$ The link between absolute federal sovereignty and preemption, however, is left quite unclear.

In this Essay, I label the type of analysis used by the majority opinion "plenary power preemption." The plenary power doctrine is one of the

\footnotetext{
'132 S. Ct. 2492, 2497 (2012).

${ }^{2}$ David A. Martin, Reading Arizona, 98 Va. L. Rev. In Brief 41, 41 (2012), http://www. virginialawreview.org/inbrief/2012/04/14/Martin_Web.pdf.

${ }^{3}$ Ga. Latino Alliance for Human Rights v. Governor of Ga., 691 F.3d 1250, 1267-68 (11 th Cir. 2012) (upholding Georgia's "papers please" statute); Hispanic Interest Coal. of Ala. v. Governor of Ala., 691 F.3d 1236, 1249-50 (11 th Cir. 2012) (striking down much of Alabama's statute).

${ }^{4}$ Arizona, 132 S. Ct. at 2498.

${ }^{5}$ Id. (quoting U.S. Const. art I, § 8, cl. 4).

${ }^{6}$ See Martin, supra note 2 , at 45 .
} 
oldest features of immigration law. ${ }^{7}$ Under this doctrine, courts give extraordinary deference to federal legislative and executive action in the immigration context, even where federal action abridges individuals' constitutional rights. ${ }^{8}$ The logic behind the plenary power doctrine is that national sovereignty requires broad federal control and discretion in fields touching on foreign affairs. ${ }^{9}$

In theory, plenary power applies in cases of individual constitutional rights, where it insulates the political branches from claims challenging their actions. In preemption cases such as Arizona, however, courts import the values and logic underlying the plenary power doctrine, even where their preemption analysis does not or cannot explicitly recognize the work that national sovereignty is doing. It is as if a very heavy thumb has been placed on the federal government's side of the scale. In some cases, the "thumb" may be quite visible, as in Justice Kennedy's Arizona opinion. But even in Arizona, where the Court gave four whole pages to its analysis of national sovereignty, there is no clear link between this analysis and the preemption holding. The Court's paean to federal power, I argue, serves as a kind of rhetorical "penumbra," radiating out over the preemption analysis even though its relevance is ambiguous at best.

Understanding how courts use plenary power preemption has important implications for understanding the likelihood of federal preemption in cases implicating immigration issues. As I will show, the "core" aspects of immigration - admissions and removals of noncitizens-are generally thought to be uniquely federal, and state action in this area will be preempted on a structural preemption theory. ${ }^{10}$ But when courts must grapple with statutes that regulate immigration more tangentially, the doctrine becomes murky. In these circumstances, states often regulate in a way that is arguably well within the scope of their traditional police

\footnotetext{
${ }^{7}$ See Sarah H. Cleveland, Powers Inherent in Sovereignty: Indians, Aliens, Territories, and the Nineteenth-Century Origins of Plenary Power over Foreign Affairs, 81 Tex. L. Rev. 1, 10 (2002) (tracing plenary power doctrine to the $1880 \mathrm{~s}$ ).

${ }^{8}$ See Hiroshi Motomura, Immigration Law After a Century of Plenary Power: Phantom Constitutional Norms and Statutory Interpretation, 100 Yale L.J. 545, 574 (1990) (describing plenary power doctrine); see also Adam B. Cox, Citizenship, Standing, and Immigration Law, 92 Calif. L. Rev. 373, 378-79 (2004) (describing the scope of the doctrine).

${ }^{9}$ See Cleveland, supra note 7 , at 4 .

${ }^{10}$ See DeCanas v. Bica, 424 U.S. 351, 355 (1976) (describing regulation of immigration as "essentially a determination of who should or should not be admitted into the country, and the conditions under which a legal entrant may remain").
} 
powers, but simultaneously might affect immigration flows. In these cases-commonly referred to as "alienage" rather than "immigration" cases-the role of sovereign power is less clear. States claim to be operating pursuant to their traditional police powers, while the federal government claims that their actions are bleeding over into immigration law, and thus are implicating sovereign power. Where courts can simply preempt state alienage law using an express or conflict preemption theory, they sometimes do. "In many cases, however, courts need more ammunition, and thus they bring national sovereignty arguments into their opinions to bolster their conflict preemption holdings.

The Court's use of plenary power preemption has the potential to create confusion, because it is difficult to predict in advance when the Court will choose to invoke federal sovereignty concerns when analyzing a state law that touches on immigration issues. Much of this doctrinal confusion, I argue, results from the constantly changing scope of state police powers and federal immigration power. The federal government has an increasingly broad reach into traditionally state-centered areas of law. Correspondingly, the scope of state police powers has changed over the past two hundred years. Further complicating matters is the fact that federal and state regulations have been increasingly intertwined, making it far more likely that the exercise of power will overlap. ${ }^{12}$ As a result, it is difficult to categorize a particular regulation with any certainty as an exercise of state police power or of federal immigration power. Instead, courts tend to fall back on broad and nebulous references to sovereign power and the need for exclusive federal authority in any case that might affect foreign affairs, no matter how tangential$1 y .^{13}$

\footnotetext{
${ }^{11}$ See Caleb Nelson, Preemption, 86 Va. L. Rev. 225, 226-29 (2000) (identifying forms of preemption analysis).

${ }_{12}$ Juliet P. Stumpf, States of Confusion: The Rise of State and Local Power over Immigration, 86 N.C. L. Rev. 1557, 1582 (2008) (discussing overlapping immigration regulation); $c f$. Ernest A. Young, "The Ordinary Diet of the Law": The Presumption Against Preemption in the Roberts Court, 2011 Sup. Ct. Rev. 253, 254 (noting that from the New Deal onward, there has been a trend toward concurrent federalism, in which the federal and state governments exercise concurrent power, and a move away from "dual federalism," in which they each exercise power in separate spheres).

${ }^{13}$ Cf. Adam B. Cox \& Cristina M. Rodriguez, The President and Immigration Law, 119 Yale L.J. 458, 461 (2009) (arguing that the Court's heavy reliance "in its reasoning on the concept of national sovereignty to justify the federal government's power over immigration" has made the contours of the power with regard to executive and legislative functions abstract and unclear).
} 
The scholarly literature on state immigration regulation has been robust and voluminous in the last few years, with some scholars advocating a shift to state regulation to fill an enforcement gap allegedly left open by the federal government, ${ }^{14}$ others pushing for increased state enforcement because immigration has increasingly local effects, ${ }^{15}$ and still others decrying the state enforcement trend as likely to lead to racial profiling, discrimination, and disuniformity. ${ }^{16}$ My goal here is not to revisit these debates. I do not take a position on whether state or local immigration enforcement is a good idea as a matter of public policy, or even a normative constitutional position, on whether immigration itself is an exclusively federal power. ${ }^{17}$

This Essay's goal is more modest, but my hope is that it will help clarify our understanding of preemption in the immigration field. I seek to explicate what courts-with a focus on the United States Supreme Court-are actually doing when they decide immigration and alienage preemption cases. ${ }^{18}$ I identify a mode of preemption that the Court engages in without explicitly acknowledging what it is doing. Understanding this doctrinal move may help us to articulate why this approach can seem so unpredictable and unsatisfying, and may also uncover some

${ }^{14}$ See, e.g., Kris W. Kobach, Attrition Through Enforcement: A Rational Approach to Illegal Immigration, 15 Tulsa J. Comp. \& Int'l L. 155, 156-58 (2008).

${ }^{15}$ See, e.g., Peter H. Schuck, Taking Immigration Federalism Seriously, 2007 U. Chi. Legal F. 57, 92; Peter J. Spiro, The States and Immigration in an Era of Demi-Sovereignties, 35 Va. J. Int'l L. 121, 154 (1994).

${ }^{16}$ See, e.g., Gabriel J. Chin \& Marc L. Miller, The Unconstitutionality of State Regulation of Immigration Through Criminal Law, 61 Duke L.J. 251, 310-12 (2011); Michael A. Olivas, Immigration-Related State and Local Ordinances: Preemption, Prejudice, and the Proper Role for Enforcement, 2007 U. Chi. Legal F. 27, 35-36 (2007); Huyen Pham, The Constitutional Right Not to Cooperate? Local Sovereignty and the Federal Immigration Power, $74 \mathrm{U}$. Cin. L. Rev. 1373, 1377-78 (2006); Michael J. Wishnie, Laboratories of Bigotry? Devolution of the Immigration Power, Equal Protection, and Federalism, 76 N.Y.U. L. Rev. 493, 553-58 (2001).

${ }^{17}$ For an argument that early case law suggests that the power over core immigration functions is not exclusively federal, see Clare Huntington, The Constitutional Dimension of Immigration Federalism, 61 Vand. L. Rev. 787, 792 (2008).

${ }_{18}$ In identifying plenary power preemption as a distinct form of preemption, my argument differs from those made by scholars who take a normative view on what form of immigration preemption is constitutionally required. See, e.g., Patrick J. Charles, Recentering Foreign Affairs Preemption in Arizona v. United States: Federal Plenary Power, the Spheres of Government, and the Constitutionality of S.B. 1070, 60 Clev. St. L. Rev. 133, 151-52 (2012); Lauren Gilbert, Immigrant Laws, Obstacle Preemption and the Lost Legacy of McCulloch, 33 Berkeley J. Emp. \& Lab. L. 153, 183-204 (2012); Erin F. Delaney, Note, In the Shadow of Article I: Applying a Dormant Commerce Clause Analysis to State Laws Regulating Aliens, 82 N.Y.U. L. Rev. 1821, 1827, 1844 (2007). 
hidden virtues. I identity two potential effects: Plenary power preemption may allow the Court to avoid the thorny question of the scope of the Executive's power in the immigration context, and the doctrine provides a substitute mechanism for protecting noncitizens from discrimination where equal protection doctrine is not up to the task.

The Essay proceeds as follows. Part I gives a short introduction to the preemption doctrine that applies in most preemption cases, immigration or not. Part II introduces the exceptional way in which courts treat preemption in cases implicating core immigration functions. Part III shows how, in cases that touch on immigration but do not implicate admissions or removals (so-called "alienage" cases), courts should in theory apply traditional express, field, or conflict preemption doctrines, but instead often apply what I call "plenary power preemption." Part IV explores the version of plenary power preemption at work in Arizona. Part $\mathrm{V}$ concludes by exploring the effects that this form of preemption has on the Court's deference to the Executive and its treatment of noncitizens.

\section{MODES OF PREEMPTION}

Preemption doctrine, at least on its face, affects all doctrinal categories, applying with equal force to the adjudication of conflicts between state and federal law whether the subject matter in question is environmental law, intellectual property law, criminal law, or immigration law. In practice the context makes an enormous difference, but in theory, the same principles of preemption apply across the board.

Before deciding a preemption case, a court must first determine whether the federal and state governments have the power to legislate in the area under consideration at all. In some cases, a court may decide that the federal government has usurped state authority; for example, in United States v. Morrison the United States Supreme Court invalidated parts of the Violence Against Women Act for just that reason. ${ }^{19}$ In a case like that, the question is not whether state law is preempted; instead, it is whether Congress has the power to legislate in the area at all. Likewise, there are some areas in which states simply have no power to act. As we shall see, the "core" functions of immigration law-the admission and removal of noncitizens-are commonly understood as exclusively federal. If a state were to attempt to regulate squarely within an exclusively federal area such as this one, a court might say it is "structurally

${ }^{19} 529$ U.S. 598, 627 (2000). 
preempted" from doing so, as that function has been assigned solely to the federal government. ${ }^{20}$

In the vast majority of cases, however, both the state whose statute is at issue and Congress can plausibly claim that they are legislating subject to a legitimate power to do so. ${ }^{21}$ In these cases, courts apply one of several preemption doctrines depending on the circumstances. Undergirding all of these tests is the Constitution's Supremacy Clause, which declares that federal law "shall be the supreme Law of the Land; and the Judges in every State shall be bound thereby, any Thing in the Constitution or Laws of any State to the Contrary notwithstanding."22 Federal law, then, has priority if a "contrary" state law exists; the preemption doctrines are devoted to discerning what exactly the content of federal law is, so courts can decide whether a state statute is "contrary" to it. Sometimes it is fairly easy to tell. If Congress has explicitly declared, for example, that a law it passed has preemptive effect, courts will declare a state statute "expressly preempted." ${ }^{23}$ But often when Congress and a state legislature have each passed a statute and it is unclear what Congress was trying to do, it becomes difficult to tell whether the two create a conflict that should result in the invalidation of the state law.

In these circumstances, courts apply either "field preemption" or "conflict preemption." Courts first ask whether Congress has intended to "occupy the field"; if so, the state law is preempted. ${ }^{24}$ Often, a court must define for itself what the "field" in question is. Rarely will Congress have so completely occupied a broad field that there can be no state legislation whatsoever, but by narrowing the field in question, a court can determine that Congress has occupied a smaller field. Congress may have done this expressly or impliedly. Implied field preemption exists where the "scheme of federal regulation" is "so pervasive as to make reasonable the inference that Congress left no room for the

\footnotetext{
${ }^{20}$ See Chin \& Miller, supra note 16 , at 268 (setting forth a jurisprudential framework under which control over immigration is entrusted exclusively to the federal government because states have no authority in the area whatsoever); Huntington, supra note 17, at 791 (explaining structural preemption).

${ }_{2}$ See Nelson, supra note 11 , at 225 (stating that "nearly every federal statute addresses an area in which the states also have authority to legislate (or would have such authority if not for federal statutes)").

${ }^{22}$ U.S. Const. art. VI, cl. 2.

${ }^{23}$ See, e.g., Crosby v. Nat'l Foreign Trade Council, 530 U.S. 363, 372 (2000) (describing types of preemption).

${ }^{24}$ Id.
} 
States to supplement it,"25 or where "the federal interest is so dominant that the federal system will be assumed to preclude enforcement of state laws on the same subject."26 The first justification essentially asks whether Congress has legislated in such a sweeping manner that it must have intended to take care of everything. The latter justification leaves open the possibility of field preemption even in circumstances where Congress has legislated very little, if the interest at stake is predominantly a federal one.

If a court finds that a statute is not subject to field preemption, then it will determine whether conflict preemption applies. Conflict preemption essentially asks whether the state law is in such conflict with the federal regulatory scheme that the state law undermines the federal scheme. It could do this in one of two ways: by making it "impossible for a private party to comply with both state and federal law," or by "stand[ing] as an obstacle to the accomplishment and execution of the full purposes and objectives of Congress"-known, respectively, as "impossibility preemption" and "obstacle preemption."27

As this description suggests, preemption doctrine is messy. There are many species of it-structural, field, conflict, and conflict's two subspecies, obstacle and impossibility - and some of these, such as field preemption, can be express or implied. Current preemption doctrine, however, is simple in one important respect: most of the cases are obstacle preemption cases. ${ }^{28}$ That is because a state will rarely legislate in a clearly exclusively federal area. Even in circumstances where both the federal government and the states do have the ability to legislate, an express preemption clause in a federal statute can prevent states from passing contradictory legislation. It will rarely be "impossible" to conform to both federal and state law, though it clearly happens. Instead, in most cases, both the federal and state governments have a legitimate claim

\footnotetext{
${ }^{25}$ English v. Gen. Elec. Co., 496 U.S. 72, 79 (1990) (quoting Rice v. Santa Fe Elevator Corp., 331 U.S. 218, 230 (1947)).

${ }^{26}$ Rice, 331 U.S. at 230 (stating that field preemption exists if "the object sought to be obtained by the federal law and the character of obligations imposed by it may reveal the same purpose").

${ }^{29}$ Crosby, 530 U.S. at 372-73 (alterations in original) (quoting Hines v. Davidowitz, 312 U.S. 52, $67(1941))$.

${ }^{28}$ Nelson, supra note 11, at 227-29 (noting that conflict preemption "is ubiquitous" and that although the impossibility preemption subset of conflict preemption cases is "vanishingly narrow," obstacle preemption "potentially covers not only cases in which state and federal law contradict each other, but also all other cases in which courts think that the effects of state law will hinder accomplishment of the purposes behind federal law").
} 
that they have the power to legislate in the area, and the court must ascertain whether the state's legislation gets in the way of federal legislation to such an extent that it frustrates the federal purpose.

There are a few fields, however, that the Court has held clearly fall in the field preemption category. Some areas will almost always be preempted, because Congress has occupied the field or because there was no legitimate state interest in the area to begin with. For example, the Constitution gives Congress the power to "promote the Progress of Science and useful Arts, by securing for limited Times to Authors and Inventors the exclusive Right to their respective Writings and Discoveries." ${ }^{, 29}$ This exclusive grant of authority to Congress over copyright and patent law means that were a state to create its own copyright or patent system, it would be preempted, either on the theory that the state had no power whatsoever to even enter the field, or on the theory that the "federal interest is so dominant that the federal system will be assumed to preclude enforcement of state laws on the same subject." ${ }^{, 30}$ This exclusive power does not mean that there are no intellectual property preemption cases - to the contrary, the scope of the exclusive federal grant of power in that area has been widely debated and litigated ${ }^{31}$ - but it does mean that if a state statute clearly falls within the scope of the constitutional clause, it will be struck down. In contrast, there are some areas of law-environmental law and antitrust law come to mind-where there is no constitutional grant of power to Congress over the field. ${ }^{32}$ There are not very many "fields" for which Congress has a specific, textual grant of power. Instead, Congress often acts pursuant to its commerce power or taxing power, and a state law will be generally preempted when Congress has "occupied the field" by legislating in the area extensively or, more commonly, when conflict preemption theory applies, but not because that field is "exclusively federal.",33

${ }^{29}$ U.S. Const. art. I, $\S 8, \mathrm{cl} .8$.

${ }^{30}$ Rice, 331 U.S. at 230.

${ }^{31}$ See, e.g., William Patry, The Enumerated Powers Doctrine and Intellectual Property: An Imminent Constitutional Collision, 67 Geo. Wash. L. Rev. 359, 370 (1999) (arguing for a narrow reading of the intellectual property clause).

${ }^{32}$ California v. ARC Am. Corp., 490 U.S. 93, 102 (1989) (stating that Congress has not preempted the field of antitrust law)

${ }^{33}$ Sometimes, Congress creates a "new" field in which it did not traditionally operate (but may, under its broad taxing, spending, and commerce powers), and invites "cooperative federalism." In these circumstances, the Court has often found that Congress intended to grant states "latitude" in their compliance with federal requirements. See, e.g., Wis. Dep't of Health \& Family Servs. v. Blumer, 534 U.S. 473, 496-98 (2002) (finding Wisconsin's 
The previous explication of preemption doctrine applies in all circumstances. But what happens when the statutes in question are immigration statutes? The answer to this question turns on the definition of "immigration." If the statute in question regulates what are sometimes referred to as the "core" immigration functions-admission and removal of noncitizens-then the statute will likely be preempted using a structural or field preemption theory. Imagine, for example, that Arizona had, rather than passing S.B. 1070, enacted a law that required all entrants into Arizona to gain permission from the state prior to entry by creating its own visa system for non-Arizonans. Or imagine Arizona passed a statute making certain characteristics-being Latino, or committing a misdemeanor-grounds for deportation. These would be clear instances of Arizona attempting to exercise a power over the core immigration functions of admission and removal. Courts would undoubtedly strike down Arizona's statute, either by holding it structurally preempted because the immigration power lies solely in the hands of the federal government, or because the second rationale for field preemption applies-the immigration power is one that is so federal that it must be exclusive, regardless of whether Congress has acted. ${ }^{34}$

In contrast, if the statute regulated more auxiliary aspects of immigration by regulating the activities of noncitizens present in the state-often called "alienage law"-instead of "immigration law," it is less obvious that the statute would be preempted. Here, a court's analysis would track the same kind of analysis that any other case would involve-field preemption if a small sub-field of alienage law (such as "alien registration"35) has been occupied by Congress, or conflict preemption if Congress has not occupied the field.

In theory then, there should be a strict line between the immigration preemption cases and the alienage preemption cases. The immigration cases involve a power exclusively granted to Congress; the alienage cases do not. But in practice, the language that courts use in the alienage preemption cases often imports some of the exclusive federal power lan-

method for determining income eligibility for Medicaid not preempted by federal law); see also Lukhard v. Reed, 481 U.S. 368, 383 (1987) (plurality opinion) (concluding that Virginia's policy of treating personal injury awards as income rather than resources under the federal welfare program was reasonable and consistent with federal law).

${ }^{34}$ See Huntington, supra note 17, at 851 (analyzing constitutional basis of structural and field preemption in immigration law).

${ }^{35}$ See Arizona, $132 \mathrm{~S}$. Ct. at 2502 (striking down Arizona's registration statute on a field preemption theory). 
guage from the immigration preemption cases. Understanding the origins of the "exclusive" federal immigration power can help us to understand why.

\section{IMMIGRATION PREEMPTION}

The early preemption cases held that federal power over immigration, as exercised over and against the states, stemmed from the power to regulate foreign commerce. ${ }^{36}$ Unlike other contexts, such as copyright and patent law, this exclusivity did not result from a textual grant of power in the Constitution. Indeed, there is no explicit power over immigration mentioned in the Constitution. The most analogous provision to a textual immigration power is the Article I grant of power to Congress to "establish an uniform Rule of Naturalization." ${ }^{, 37}$ But the power to decide who may become a citizen is much narrower than the power to determine who may enter or reside within the territorial bounds of the nation; the naturalization power does not comfortably cover all of immigration. ${ }^{38}$ Aside from this, the other bases of the power are more speculative. Perhaps, for example, immigration is a form of commerce in people, so Congress has power to regulate it under the Commerce Clause; ${ }^{39}$ or perhaps the power to regulate immigration is simply a power inherent in sovereignty-every sovereign nation must be able to control its borders, or by definition it would not be a sovereign nation. ${ }^{40}$

Prior to 1875 , states were the primary actors in the immigration field, though they did not identify their regulation as "immigration" law. Instead, states enacted laws regulating the entry of people into the statesrestricting paupers, for example, or free blacks or slaves. ${ }^{41}$ These restrictions applied regardless of whether the person was migrating across state boundaries or international ones. The mid-nineteenth century saw a struggle between the states and a relatively inactive federal government for control over the migration of people, which was resolved in favor of

\footnotetext{
${ }^{36}$ Chy Lung v. Freeman, 92 U.S. 275, 280 (1875); Henderson v. Mayor of New York, 92 U.S. 259, 270 (1875).

${ }^{37}$ U.S. Const. art. I, $\$ 8$, cl. 4.

${ }^{38}$ See Thomas Alexander Aleinikoff et al., Immigration and Citizenship: Process and Policy 189 (7th ed. 2012).

${ }^{39}$ Chy Lung, 92 U.S. at 280.

${ }^{40}$ Chae Chan Ping v. United States, 130 U.S. 581, 585 (1889).

${ }^{41}$ See Gerald L. Neuman, Strangers to the Constitution: Immigrants, Borders, and Fundamental Law 35 (1996).
} 
the federal government in the $1870 \mathrm{~s}^{42}$ In 1875 , Congress passed the first restrictive immigration law; ${ }^{43}$ the next year, the Supreme Court struck down immigration statutes passed by the California, New York, and Louisiana legislatures on the theory that because Congress had the power to regulate foreign commerce, it also had the near-exclusive power to regulate immigration.

It is worth looking closely at what the Court in 1876 thought "immigration" meant when it said that immigration was an exclusively federal power. Two of the statutes, passed by the legislatures of New York and Louisiana, required the owners of vessels landing foreign passengers to post bonds of three hundred dollars for each passenger to indemnify the state against their becoming public charges before a ship could land. ${ }^{44}$ These acts did not exclude immigrants per se, but they did substantially burden immigration by taxing immigrants' landing. ${ }^{45}$ This burdening of immigration, the Court held, was a regulation of commerce, a power exclusively vested in the federal government. ${ }^{46}$

New York and Louisiana claimed, just as Arizona claimed recently, that they were not regulating immigration or commerce, but were exercising their state police powers. These powers were very broad, encompassing "the protection of the lives, health, and property of the citizens, and ... the preservation of good order and the public morals. ${ }^{, 47}$ Unlike today, where both the state and federal governments are simultaneously involved in the regulation of many core legal functions, the states were "the primary arena for dealing with a host of policy issues, including ed-

\footnotetext{
${ }^{42}$ See Passenger Cases, 48 U.S. (7 How.) 283, 572 (1849) (striking down New York law taxing arriving alien passengers; there was no majority opinion, eight Justices issued separate opinions and the votes fell 5-4 in favor of striking down the law); Mayor of New York v. Miln, 36 U.S. (11 Pet.) 102, 113 (1837) (upholding New York law requiring ship masters to submit reports on the names and personal information of all arriving passengers as falling within New York's state police powers).

${ }^{43}$ Act of Mar. 3, 1875 (Page Law), ch. 141, § 1, 18 Stat. 477 (repealed 1974).

${ }^{44}$ Henderson v. Mayor of New York, 92 U.S. 259, 267, 275 (1875).

${ }^{45}$ Id. at 268 (stating that "if it is apparent that the object of this statute . . . is to compel the owners of vessels to pay a sum of money for every passenger brought by them from a foreign shore, and landed at the port of New York, it is as much a tax on passengers if collected from them, or a tax on the vessel or owners for the exercise of the right of landing their passengers in that city, as was the statute held void in the Passenger Cases").

${ }^{46}$ Id. at 271 (stating that "a rule emanating from any lawful authority, which prescribes terms or conditions on which alone the vessel can discharge its passengers, is a regulation of commerce; and, in case of vessels and passengers coming from foreign ports, is a regulation of commerce with foreign nations").

${ }^{47}$ Beer Co. v. Massachusetts, 97 U.S. 25, 33 (1877).
} 
ucation, most criminal justice functions, and the regulation of public utilities and intrastate transportation." ${ }^{, 48}$ Indeed, the state police powers were the source of the states' early involvement in immigration law, as discussed above. ${ }^{49}$

In Henderson, however, the Court swept this rationale aside as purely semantic. "Nothing is gained in the argument by calling it the police power," Justice Miller explained:

Very many statutes, when the authority on which their enactments rest is examined, may be referred to different sources of power, and supported equally well under any of them. A statute may at the same time be an exercise of the taxing power and of the power of eminent domain. A statute punishing counterfeiting may be for the protection of the private citizen against fraud, and a measure for the protection of the currency and for the safety of the government which issues it. It must occur very often that the shading which marks the line between one class of legislation and another is very nice, and not easily distinguishable. $^{50}$

In this brief statement, Justice Miller articulated the problem that was to haunt immigration preemption (and foreign affairs preemption, generally) for years to come. It is quite possible for a state to consider itself to be protecting its citizens from crime or immorality and simultaneously possible for the federal government to view the state's actions as affecting foreign commerce or immigration. For statutes like those at issue in Henderson, the Court made it clear that reframing a question in terms of state police power would be of no help if the statute affected the entry of noncitizens into the country.

Chy Lung v. Freeman, decided the same day as Henderson, gave further explication of why the immigration power must be exclusively fed-

\footnotetext{
${ }^{48}$ Patrick M. Garry, Federalism's Battle with History: The Inaccurate Associations with Unpopular Politics, 74 UMKC L. Rev. 365, 380 (2005); see also Jacobson v. Massachusetts, 197 U.S. 11, 24-25 (1905) (holding that states had the power to order the compulsory vaccination of adults for smallpox).

${ }^{49}$ See Miln, 36 U.S. (11 Pet.) at 139 (holding that the police powers included every law or statute concerning the whole or any part of the people, "whether it related to their rights, or their duties, whether it respected them as men, or as citizens of the state; whether in their public or private relations; whether it related to the rights of persons, or of property, of the whole people of a state, or of any individual within it").

${ }^{50}$ Henderson, 92 U.S. at $271-72$.
} 
eral. ${ }^{51}$ Unlike the New York and Louisiana statutes, the California statute did not require a bond for every arriving passenger. Instead, it required ship masters to post bond for any passenger deemed to be a "lewd or debauched woman," "a convicted criminal," "lunatic, idiotic, deaf, dumb, blind, crippled, or infirm," or "likely to become permanently a public charge." ${ }^{.52}$ In addition, the statute gave the port commissioner enforcing it much more discretion than the New York or Louisiana statutes gave; a vessel owner could avoid posting bond by paying the commissioner "such a sum of money as the commissioner may in each case think proper to exact." ${ }^{13}$ A Chinese woman, detained as a "lewd and debauched woman" under the statute, with twenty-one others traveling on the same ship, challenged the California statute all the way to the Supreme Court. As with the New York and Louisiana statutes struck down in Henderson, the Court struck down the California statute as an impermissible infringement on the federal commerce power. ${ }^{54}$

The Court's reasoning in Chy Lung invoked the unique nature of foreign relations as a rationale for federal exclusivity in the admission of immigrants. If the California statute were to stand, "a single State [could], at her pleasure, embroil us in disastrous quarrels with other nations. $" 55$ Of course, Congress itself could create an international conflict through poorly conceived immigration policy. It had, in fact, recently passed a law that looked remarkably similar to California's-the Page Law of $1875 .{ }^{56}$ The problem, rather, was that a state's policy could be misunderstood as national sentiment. Or, as the Court explained in Chy Lung:

[I]f this plaintiff and her twenty companions had been subjects of the Queen of Great Britain, can any one doubt that this matter would have been the subject of international inquiry, if not of a direct claim for redress? Upon whom would such a claim be made? Not upon the State of California; for, by our Constitution, she can hold no exterior rela-

${ }^{51} 92$ U.S. at 280.

52 Act of Mar. 30, 1874, ch. 610, § 70, 1873-1874 Acts Amendatory of the Codes of Cal., 39-40, invalidated by Chy Lung, 92 U.S. at 277-80.

${ }^{53}$ Chy Lung, 92 U.S. at 278.

${ }^{54}$ Id. at 280.

${ }^{55} \mathrm{Id}$.

${ }^{56}$ See Page Law, ch. $141, \S 1,18$. 
tions with other nations. It would be made upon the government of the United States. ${ }^{57}$

The nation as a whole would have to pay for California's blunders.

Chy Lung and Henderson, then, stood for the proposition that immigration is an exclusively federal power rooted in the commerce power because it has the potential to influence foreign affairs - what courts today would call "structural preemption" or, perhaps, "field preemption," where the core functions of immigration law are the field in question. This understanding of immigration regulation as an exclusively federal power is one of the two pillars of what immigration scholar Professor Hiroshi Motomura has termed "immigration exceptionalism." preemption context, immigration is "exceptional" in that it implicates uniquely federal concerns.

But there is another side to immigration exceptionalism that is equally important: the deference with which constitutional challenges to federal immigration statutes are treated by courts. This doctrine, commonly known as "the plenary power doctrine," justifies immigration exceptionalism not because of the uniquely federal interests at stake but because of the uniquely political interests at stake. It shares its roots, however, with structural immigration preemption concerns regarding the unique nature of foreign affairs.

The plenary power doctrine developed just a few years after Chy Lung and Henderson, when the Supreme Court was called upon to determine the constitutionality of racially discriminatory laws excluding Chinese immigrants and targeting them for deportation. In those casesChae Chan Ping (commonly known as the Chinese Exclusion Case), $\mathrm{Ni}$ shamura Ekiu, and Fong Yue Ting - the Supreme Court borrowed from the language of the earlier preemption cases to bolster the claim of sovereign power. ${ }^{59}$ Under the plenary power doctrine as developed in those and later cases, immigration is put into the same box as foreign affairs, governance of territories, and legislation regarding Native American

\footnotetext{
${ }^{57}$ Chy Lung, 92 U.S. at 279.

${ }^{58}$ Hiroshi Motomura, Federalism, International Human Rights, and Immigration Exceptionalism, 70 U. Colo. L. Rev. 1361, 1363-64 (1999).

${ }_{59}$ Fong Yue Ting v. United States, 149 U.S. 698, 711-12 (1893); Nishimura Ekiu v. United States, 142 U.S. 651, 659 (1892); Chae Chan Ping v. United States, 130 U.S. 581, 603-04 (1889). See Fong Yue Ting, 149 U.S. at 712 (noting that "[t]he Constitution has granted to Congress the power to regulate commerce with foreign nations, including ... the bringing of persons into the ports of the United States").
} 
tribes, all areas in which the Supreme Court has recognized the executive and legislative branches' superior competence over the judicial branch. ${ }^{60}$ As with the structural preemption enjoyed by immigration statutes, the plenary power doctrine exists despite the lack of a clear textual commitment of this power to Congress. The plenary power doctrine also extends over the same subject matter as structural preemption-the core immigration functions of admission of noncitizens and their removal. $^{61}$

Although "plenary" simply means "absolute," the meaning of "absolute" power in the immigration context is quite different than in the Commerce Clause context, where the "plenary" nature of the power primarily influences the relationship between the federal government and the states. ${ }^{62}$ In the immigration context, "plenary power" ultimately means courts will scrutinize a federal statute regulating immigration under a standard that is very generous to the federal government. The case law is not entirely clear on whether this standard is rational basis review or something even lower, but two things are clear: Courts can review the claim (this is not an abstention doctrine), and the normal heightened scrutiny for protected classes or fundamental rights will not apply ${ }^{63}$ As Professor Stephen Legomsky has explained, "When regulating immigration, Congress may discriminate on the basis of race. It may discriminate on the bases of gender and legitimacy. It may restrict noncitizens' political speech without having to establish a clear and present danger. With some qualifications, Congress may disregard procedural due process when excluding aliens. ${ }^{364}$ This lower standard of review does not apply

\footnotetext{
${ }^{60}$ See Cleveland, supra note 7 , at 15,77 ; see also Fong Yue Ting, 149 U.S. at 711-12; Nishimura Ekiu, 142 U.S. at 659; Chae Chan, 130 U.S. at 603-04.

${ }^{61}$ See Fong Yue Ting, 149 U.S. at 711 (noting that "[t]he right to exclude or to expel all aliens, or any class of aliens, absolutely or upon certain conditions, in war or in peace [is] an inherent and inalienable right of every sovereign and independent nation, essential to its safety, its independence and its welfare").

${ }^{62}$ The Supreme Court has declared that " "[o]ver no conceivable subject is the legislative power of Congress more complete than it is over' the admission of aliens." Kleindienst $v$. Mandel, 408 U.S. 753, 766 (1972) (quoting Oceanic Steam Navigation Co. v. Stranahan, 214 U.S. $320,339(1909))$.

${ }^{63}$ Fiallo v. Bell, 430 U.S. 787, 792-95 (1977) (remarking that "in the exercise of its broad power over immigration and naturalization, 'Congress regularly makes rules that would be unacceptable if applied to citizens"' (quoting Mathews v. Diaz, 426 U.S. 67, 80 (1976))).

${ }^{64}$ Stephen H. Legomsky, Immigration and the Judiciary: Law and Politics in Britain and America 178 (1987); see also Fiallo, 430 U.S. at 799-800 (upholding sex- and illegitimacybased discriminatory immigration statute); Harisiades v. Shaughnessy, 342 U.S. 580, 595-96
} 
only to cases brought by immigrants. In many cases, it is the citizen parent, spouse, or child of the immigrant who brings the claim, or the citizen who wishes to exercise his or her First Amendment rights to associate with or speak with the immigrant. ${ }^{65}$ Nevertheless, these are still conconsidered "immigration" cases if they deal with admissions or removal, and the plenary power doctrine thus applies.

As a doctrinal matter, plenary power and structural immigration preemption are distinct concepts. But the early cases articulating the two doctrines drew on the same logic, explaining the lack of constitutional textual grant of power to Congress as unproblematic because of the structural needs of national sovereignty. Indeed, these two pillars of immigration exceptionalism are so intertwined that courts and scholars sometimes refer to structural preemption as an aspect of plenary power. Some scholars, for example, refer to "plenary power" as "preemptive of state efforts to encroach on such power, ${ }^{, 66}$ while others argue that courts should explicitly invoke the plenary power doctrine in preempting state anti-immigrant laws. ${ }^{67}$ Perhaps Professor Peter Schuck describes the relationship between plenary power and preemption most accurately when he describes the use of sovereignty arguments in the preemption context as a "corollary" to the plenary power doctrine, in which "federal power is indivisible" even when unexercised in the same way that federal power over interstate commerce includes a "dormant" power. ${ }^{68}$ The two con-

(1952) (upholding associational restriction); Chae Chan Ping, 130 U.S. at 609-10 (upholding national origin-based exclusion).

${ }^{85}$ See Fiallo, 430 U.S. at 794-95; Harisiades, 342 U.S. at 584; see also Reno v. Arab-Am. Anti-Discrimination Comm., 525 U.S. 471, 475 (1999).

${ }^{66}$ Stephen Lee, Monitoring Immigration Enforcement, 53 Ariz. L. Rev. 1089, 1133 (2011); see also Rose Cuison Villazor, Rediscovering Oyama v. California: At the Intersection of Property, Race, and Citizenship, 87 Wash. U. L. Rev. 979, 1032-33 n.331 (2010) (stating that courts generally accept the argument that local governments' anti-immigrant laws "are in fact preempted by Congress's plenary power over immigration").

${ }^{67}$ Karla Mari McKanders, Welcome to Hazelton! "Illegal" Immigrants Beware: Local Immigration Ordinances and What the Federal Government Must Do About It, 39 Loy. U. Chi. L.J. 1, 26-29 (2007).

${ }^{68}$ Schuck, supra note 15 , at 57 (stating that "equally canonical is the corollary notion, analogous to the dormant power doctrine in Commerce Clause jurisprudence, that this federal power is indivisible and therefore the states may not exercise any part of it without an express or implied delegation from Washington"); see also Delaney, supra note 18, at 1827 (advocating for the use of a dormant immigration power approach instead of a traditional preemption approach); Karl Manheim, State Immigration Laws and Federal Supremacy, 22 Hastings Const. L.Q. 939, 958-60 (1995) (arguing that there is a constitutional basis for a "dormant immigration clause" doctrine). 
cepts are two sides of the same national sovereignty coin; to be a truly sovereign nation, the logic goes, Congress must be able to make nationally applicable decisions about immigration matters - California cannot "embarrass" the entire nation with its policy - and it must be able to do this without interference from the courts in vindicating the rights of immigrants affected by the laws.

\section{AliEnAge PreEMPtion}

The core immigration functions of admission and removal, then, are exclusively federal, and will always preempt state efforts to legislate in the area ("structural preemption"). These functions are so important to national security and national control over foreign affairs issues that when Congress acts, courts must exercise extraordinary deference, even where fundamental constitutional rights are at stake (the "plenary power doctrine"). But what about cases that are not core immigration cases? Most of the statutes passed by states, up to and including S.B. 1070, do not directly attempt to regulate immigration. Instead, they concern either enforcement-when can a police officer stop someone whom he suspects may be here illegally?--or discrimination-when can a state or locality restrict noncitizens' access to public schools, welfare, or work? None of these examples is clearly "immigration law," and in fact, most of these examples are typical of the exercise of the state police power over the health and safety of its citizens. Their immigration aspect is their ancillary impact on immigration. These statutes are what we might term "alienage" statutes (statutes that use alienage as a means of administering benefits or treating residents differently from one another), but they do not focus on the "core" immigration functions identified in the canonical structural preemption and plenary power cases. ${ }^{69}$

As a doctrinal matter, in an alienage case a court should apply the same preemption doctrine it would apply in any case that does not concern an exclusively federal power. There are numerous ways in which a court could strike down state alienage statutes without invoking structural preemption, or its close cognate, the plenary power doctrine. A court might, for example, find that a statute violates equal protection, just as the Supreme Court found with the San Francisco laundry ordi-

\footnotetext{
${ }^{69}$ Cf. Fong Yue Ting v. United States, 149 U.S. 698, 713 (1893) ("The power to exclude aliens and the power to expel them rest upon one foundation, are derived from one source, are supported by the same reasons, and are in truth but parts of one and the same power.").
} 
nance at issue in Yick $\mathrm{Wo}^{70} \mathrm{Or}$, like state statutes in many other fields, such as environmental law, the state statute might be preempted using a theory of express, field, or conflict preemption. To be sure, the roots of congressional power would matter in each of these scenarios. If Congress had no power to regulate immigration, for example, the Supremacy Clause would not magically give it power. And the nature of the power being exercised might give the court an important clue as to whether Congress was capable of "occupying the field." But Congress's power could not be plenary, or "absolute," or it would make no sense to undergo the preemption analysis at all.

Instead, however, in most of the preemption cases challenging state alienage statutes that the Supreme Court has heard, the Court has applied an analysis that folds in the national sovereignty concerns from the structural preemption and plenary power cases, by construing the specific alienage regulation as regulations of immigration in disguise. In each of these cases, the state in question was attempting to regulate in a way that seemed, at the time, to be clearly within its traditional police powers. In cases where the Court struck down the legislation, it generally did so by construing the exercise of state police power as an impermissible encroachment on the federal immigration power, implicating the same national sovereignty issues at play in the plenary power context.

Take, for example, Truax v. Raich, where the Court struck down a law that required employers to employ not less than eighty percent qualified electors or native-born citizens. ${ }^{71}$ The Court construed the law as denying noncitizens "the opportunity of earning a livelihood," and said that this was "tantamount to the assertion of the right to deny them entrance and abode, for in ordinary cases they cannot live where they cannot work." 72 In Takahashi v. Fish \& Game Commission, the Court used similar logic to reject California's claim that it was fulfilling a "special public interest" by banning residents who were ineligible for citizenship (in other words, Japanese) from commercial fishing in California's coastal waters, emphasizing that the law prohibited residents "from making a living by fishing." ${ }^{.73}$ More recent cases made similar moves; in Graham v. Richardson, for example, the Court invalidated state laws limiting welfare eligibility to U.S. citizens or long-time lawful residents,

\footnotetext{
${ }^{70}$ Yick Wo v. Hopkins, 118 U.S. 356, 373-74 (1886).

${ }^{71} 239$ U.S. 33 (1915).

${ }^{72}$ Id. at 42 .

${ }^{73} 334$ U.S. 410, 420-21 (1948).
} 
analogizing access to welfare to the access to work discussed in Truax and Takahashi. ${ }^{74}$

In contrast, however, the Court upheld some statutes as an exercise of the state police power despite the effect they might have on immigration. In Oyama v. California, the Court struck down portions of California's Alien Land Act that discriminated against U.S. citizens of Japanese descent, but left standing the portions of the law that precluded certain noncitizens-primarily Japanese-from owning land. ${ }^{75}$ In so doing, the Court cited previous cases in which it had upheld alien land laws as a proper exercise of states' police power. ${ }^{76}$ Similarly, in DeCanas v. Bica, the Court upheld a California statute making it a crime to hire a federally unauthorized citizen to work if the employment "would have an adverse effect on lawful resident workers." 77 The Court distinguished other preemption cases by characterizing them as "based on the predominance of federal interest in the fields of immigration and foreign affairs," in contrast to the employer sanctions at issue in DeCanas, which were "fashioned to remedy local problems, and operate[d] only on local employers." ${ }^{78}$ Oyama's affirmance of alien land acts was narrow-four Justices voted to strike down the California Act altogether-and it crumbled as useful precedent when states (including California) rejected the propriety of these acts as unconstitutional violations of equal protection and due process. ${ }^{79}$ DeCanas, however, has lived on as the best example of a permissible state-based immigration law, and has been a cornerstone of the litigation strategy of those advocating for laws such as the one passed by Arizona.

In both these contexts-land ownership and employment regulationthe state police power was clearly a traditional way to understand the

\footnotetext{
${ }^{74} 403$ U.S. 365, 371-74 (1971); see also Toll v. Moreno, 458 U.S. 1, 3, 17 (1982) (striking down Maryland's in-state tuition law, and holding that Maryland must extend in-state tuition to college students on certain non-immigrant visas who were nonetheless domiciled in the state).

${ }^{75} 332$ U.S. 633, 647 (1948). California's Alien Land Law was ultimately struck down as unconstitutional by the California Supreme Court. See Fujii v. State, 242 P.2d 617, 630 (Cal. 1952).

${ }_{76}$ Oyama, 332 U.S. at 639 n. 12 (citing Terrace v. Thompson, 263 U.S. 197 (1923); Porterfield v. Webb, 263 U.S. 225 (1923); Webb v. O'Brien, 263 U.S. 313 (1923); Frick v. Webb, 263 U.S. $326(1923))$.

77424 U.S. 351, 352 (1976) (quoting Cal. Lab. Code § 2805(a) (1971)) (internal quotation marks omitted).

${ }^{78}$ Id. at 363 .

${ }^{79}$ See Fujii, 242 P.2d at 630.
} 
legislation. But Truax and Takahashi also involved the traditional state police powers; in fact, to reach its holding regarding California's coastal fishing waters, the Court had to distinguish or repudiate years' worth of decisions on the states' authority to regulate game and wildlife within their borders. Takahashi and Oyama were both decided in 1948. Was it really true that in 1948, denying Japanese immigrants the right to make a living in commercial fishing was an "immigration" case because it could influence foreign affairs, but denying the same people right to own land (and, thus, the right to make a living by farming) was not? Likely not; what was happening underneath the surface of the cases was that the category of "state police power" was shrinking and the category of "federal immigration law" or "foreign affairs law" growing. Oyama, on this theory, represents one important turning point. The 1923 cases it relied on to avoid deciding the unconstitutionality of alien land laws assumed that real property law was a core state interest. By 1948, when Oyama was decided, the Court was uncomfortable with allowing states to extend this kind of discrimination to citizens, but refused to touch the discrimination against noncitizens. In contrast, it seems impossible that the Court today would see the refusal to allow Japanese noncitizens to own land as a simple exercise of state police power and not an encroachment on federal immigration policy. Like many of the laws struck down in $\mathrm{Ar}$ izona, an alien land law today would be seen as an attempt to stem the tide of immigration by making life in the United States as difficult as possible-or, in the words of S.B. 1070, "attrition through enforcement."

The Supreme Court's most expansive explanation of how it decides alienage preemption cases occurred in 1942, when it decided Hines $v$. Davidowitz - which involved a challenge to an Alien Registration Act passed by Pennsylvania. ${ }^{81}$ The Act, passed in 1939 in a spate of wartime anti-German fever, required noncitizens to register once a year, pay an annual registration fee, carry an alien identification card at all times, show the card to register a car or obtain a driver's license, and show the card whenever a police officer demanded it-the last provision in many ways a much simpler (and starker) version of the "show your papers" portion of Arizona's S.B. $1070 .{ }^{82}$ And, as in the Arizona case, Pennsyl-

\footnotetext{
${ }^{80}$ Support Our Law Enforcement and Safe Neighborhoods Act, ch. 113, § 12, 2010 Ariz. Sess. Laws $450-468$.

${ }^{81} 312$ U.S. 52, 56 (1941).

${ }^{82}$ Id. at 59.
} 
vania was not the only state that had enacted a similar law. ${ }^{83}$ The federal version of Pennsylvania's Act was focused more on recordkeeping and less on law enforcement; it did not require immigrants to carry or show a card, but did require fingerprinting of all registrants and criminalized willful failure to register. ${ }^{84}$

The Court struck down the Pennsylvania statute, holding that it was preempted by federal law on a conflict preemption theory. ${ }^{85}$ In his majority opinion, however, Justice Black made a similar rhetorical move to Justice Kennedy's in Arizona-after describing the statute in question and the issues at hand, he led with a section on "the supremacy of the national power in the general field of foreign affairs, including power over immigration, naturalization, and deportation." ${ }^{86}$ Culling from Henderson and the immigration plenary power cases, he justified federal power over immigration as requiring one voice: "[F]or national purposes, embracing our relations with foreign nations, we are but one people, one nation, one power. ${ }^{177}$ Quoting Chy Lung, the opinion intimated that Pennsylvania's actions threatened national security; if a state's actions led the United States "to war . . . would California alone suffer, or all the Union?"88

Having established the federal government as the sole regulator in the immigration field, the Court could have simply held that Pennsylvania did not have the authority to regulate at all in this area. But it did notperhaps because alien registration is not clearly "core" immigration law. Instead, the Court decided the case using a form of conflict preemption, inquiring whether Pennsylvania's law stood as "an obstacle to the accomplishment and execution of the full purposes and objectives of Congress." ${ }^{89}$ The Court was remarkably forthcoming about the difficulty of determining what preemption test it should use. "[We] ... [have] made use of the following expressions: conflicting; contrary to; occupying the field; repugnance; difference; irreconcilability; inconsistency; violation; curtailment; and interference," the opinion stated, "[b]ut none of these expressions provides an infallible constitutional test or an exclusive con-

\footnotetext{
${ }^{83}$ Id. at $60,61 \mathrm{n} .8$ (naming other states with alien registration laws).

${ }^{84}$ Id. at $60-61$.

${ }^{85}$ Id. at $66-67,74$.

${ }^{86}$ Id. at 62 .

${ }^{87}$ Id. at 63 .

${ }^{88}$ Id. at 64 (quoting Chy Lung v. Freeman, 92 U.S. 275, 279 (1876)).

${ }^{89}$ Id. at 67.
} 
stitutional yardstick.... [T]here can be no one crystal clear distinctly marked formula." 90

The crucial determinant for the Court was the context in which Pennsylvania passed the statute. "[I]n that determination, it is of importance that this legislation is in a field which affects international relations .... Any concurrent state power that may exist is restricted to the narrowest of limits ....".91 It seems that the Court was more lenient toward Congress in a case that was within the general ambit of foreign relations, even if it was uncertain about the scope of "immigration" or the scope of Pennsylvania's police powers. "[T] he treatment of aliens," it further explained, is "a matter of national moment." whether an alien registration law was a kind of immigration regulation: "[W] hether or not registration of aliens is of such a nature that the Constitution permits only of one uniform national system, it cannot be denied that the Congress might validly conclude that such uniformity is desirable." ${ }^{\text {"93 }}$ Hines, without saying it directly, is a "penumbra" case, where the "penumbra" comes not from an individual right but from the idea of sovereign power. The power over immigration-exclusion and removal - and its ties with foreign affairs imbues everything that touches on immigration with an immigration-like quality.

In Hines, the main problem appears to have been that the purpose of the registration scheme - and a possible result - was to make life more difficult for immigrants. The Court explained:

The imposition of distinct, unusual and extraordinary burdens and obligations upon aliens - such as subjecting them alone, though perfectly law-abiding, to indiscriminate and repeated interception and interrogation by public officials - thus bears an inseparable relationship to the welfare and tranquility of all the states, and not merely to the welfare and tranquility of one. ${ }^{94}$

Pennsylvania's act was not a "mere census." 95 Instead, it subjected immigrants to "unnecessary and irritating restrictions upon personal liberties of the individual" and would subject them "to a system of indiscrim-

\footnotetext{
${ }^{90} \mathrm{Id}$.

${ }^{91}$ Id. at $67-68$.

92 Id. at 73 .

${ }^{93} \mathrm{Id}$.

94 Id. at $65-66$.

${ }^{95}$ Id. at 66.
} 
inate questioning similar to the espionage systems existing in other lands"- something Congress had expressly decided not to do in rejecting, over many years, other alien registration bills and in crafting the one it did pass in $1940 .^{96}$

Hines may represent the clearest, most honest version of what plenary power preemption could look like. The case acknowledged the importance of the federal interest at stake, but rather than using this interest as a kind of rhetorical trump card, it carefully tied this interest into its preemption analysis by showing that the registration scheme in question really did conflict with the federal scheme and that Congress really had considered a variety of schemes and chosen a particular one, partly for foreign policy reasons. Although it could have been more explicit about the foreign policy interests at stake, Hines was decided against the backdrop of the United States' decision to engage in World War II. It seems clear that a Pennsylvania law that would impose burdens on immigrants (Germans, likely) really might have affected the delicate relations between the United States and Germany in a way that would have been counter to the federal government's goals.

Hines may have been a rather easy case; after all, alien registration is a close analogue to immigration regulation, with a slim history of state rather than federal involvement. In many cases, however, the role of sovereign power is less clear, sometimes even elliptical, and the regulation in question seems to fall squarely within the state police power. These cases are harder to fit within the boundaries of preemption doctrine, and sometimes they cannot be. An example of this phenomenon is Plyler v. Doe. ${ }^{97}$ In Plyler, the Court invalidated a Texas statute that would have banned undocumented children from attending public school unless they paid tuition to reimburse the state for the costs of educating them. ${ }^{98}$ The Plyler majority is justly famous for striking down the Texas statute on an equal protection theory. Emphasizing the importance of education in creating equal opportunities for adults, the Court held that a denial of education would deny children "the ability to live within the structure of our civic institutions, and foreclose any realistic possibility that they will contribute in even the smallest way to the progress of our

\footnotetext{
${ }^{96}$ Id. at 71

97457 U.S. 202 (1982)

${ }^{98}$ Id. at 230.
} 
Nation." 99 The Texas law, in other words, had the potential to create a permanent underclass.

But Plyler is just as important for what it did not hold - that the Texas statute was preempted by federal immigration law. Indeed, if anything, Justice Brennan's decision in Plyler appeared to give states more room to legislate in the alienage area, so long as their legislation passed intermediate scrutiny for equal protection purposes. ${ }^{100}$ Citing DeCanas-the case that upheld California's criminalization of hiring unauthorized aliens - the Court stated, "the States do have some authority to act with respect to illegal aliens, at least where such action mirrors federal objectives and furthers a legitimate state goal." ${ }^{.101}$ It is this language that made it seem plausible that statutes such as S.B. 1070 might not be preempted, despite their explicit "attrition through enforcement" goal. It appeared to reopen the possibility, shut down after Chy Lung and Henderson, of a state role in influencing admissions and deportations, even if states cannot actually create admission or deportation law per se. What would these "legitimate state goals" be? According to Plyler, they would include "an interest in mitigating the potentially harsh economic effects of sudden shifts in population" and the provision of "high-quality public education." 102 The problem in Plyler was not that these were not legitimate state goals, but that the fit between the statute and the government interest was bad. ${ }^{103}$

But just as the Court opened one potential avenue for states in Plyler, it was simultaneously taking away power from the states by continuing to expand the scope of the federal immigration power. In Mathews $v$. Diaz ${ }^{104}$ the Court held that federal laws discriminating against some noncitizens in the conferral of welfare benefits were permissible, and expressly invoked the plenary power doctrine to support the holding. Diaz did not involve exclusion or deportation, but rather the treatment of

\footnotetext{
${ }^{99}$ Id. at 223.

${ }^{100}$ See Peter Schuck, The Transformation of Immigration Law, 84 Colum. L. Rev. 1, 58 (1984) (arguing that Plyler was "the most powerful rejection to date of classical immigration law's notion of plenary national sovereignty over our borders").

${ }_{101}$ Plyler, 457 U.S. at 225 (citing DeCanas v. Bica, 424 U.S. 351 (1976)).

${ }^{102}$ Id. at 228-29.

${ }^{103}$ Id. at 228 (stating that the Texas law "hardly offers an effective method of dealing with an urgent demographic or economic problem"); id. at 229 (stating that "the record in no way supports the claim that exclusion of undocumented children is likely to improve the overall quality of education in the State").

${ }^{104} 426$ U.S. 67 (1976).
} 
noncitizens outside of the immigration context, an area traditionally understood to be alienage, not immigration, law. But in Diaz, the Court justified Congress's discriminatory treatment of noncitizens by tying it to the plenary power over immigration: Welfare benefits create an incentive for immigrants to arrive or to remain; therefore, they are a part of "immigration law." If If the conferral of welfare benefits counts as "immigration law," then what doesn't? Employment opportunities, criminal enforcement, educational access, zoning laws-all of these doctrinal categories could easily fall into the wide swath of "immigration law" claimed in Diaz. ${ }^{106}$

On the eve of the Arizona case, then, Supreme Court case law on preemption was muddled. States clearly could not regulate immigration-actual admission or deportation of noncitizens - and would be structurally preempted should they try. But they could-in theoryregulate alienage, so long as the regulation was based on a traditional state police power. The preemption cases, however, were difficult to harmonize. If the Court characterized the statute in question as involving "foreign affairs," it would fall; if not, it would stand. But almost any regulation of immigrants could in theory affect "foreign affairs," so the scope of this use of plenary power was constantly shifting.

\section{PlenARy POWER PREEMPTION IN ARIZONA}

In Arizona v. United States, the Supreme Court ruled on the constitutionality of several sections of the Support Our Law Enforcement and Safe Neighborhoods Act, commonly known as S.B. $1070 .^{107}$ Four sections of S.B. 1070 were at issue in the case. Section 3 made failure to comply with federal alien registration requirements a state misdemeanor. Section 5(C) made it a state misdemeanor for an unauthorized alien to seek or engage in work in Arizona. ${ }^{108}$ Section 6 authorized officers to arrest, without a warrant, a person "the officer has probable cause to be-

\footnotetext{
${ }^{105}$ Id. at 80 .

${ }^{106}$ The regulation of noncitizens is not the only area in which federal involvement has grown. For instance, the federal government has also become increasingly involved in real estate finance, thus potentially conflicting with traditional state control over property law. See Frank S. Alexander, Federal Intervention in Real Estate Finance: Preemption and Federal Common Law, 71 N.C. L. Rev. 293, 295 (1993) (noting that "federal law has become an element of virtually every mortgage transaction" and that "this increased federal intervention raise[s] the issue of what law governs real estate finance").

${ }^{107} 132 \mathrm{~S}$. Ct. at 2497.

${ }^{108}$ Id. at 2497-98.
} 
lieve... has committed any public offense that makes the person removable from the United States." ${ }^{109}$ And Section 2(B), often called the "papers please" provision, provided that "officers who conduct a stop, detention, or arrest must in some circumstances make efforts to verify the person's immigration status with the Federal Government." 110

Arizona promised to test the limits of preemption doctrine. Several of the sections of S.B. 1070 at issue in the case involved core state police powers-law enforcement and regulation of employment. Yet the statute also included an explicit immigration-related motive - "attrition through enforcement." 111 The stage was set for a showdown between state police power and federal power, and it was far from clear which side would win. Based on the precedents discussed above, the crucial factor the Court needed to consider was how much Arizona's law implicated foreign relations. If it intruded on them extensively, then a plenary power preemption analysis was likely. If not, then the analysis would likely resemble the conflict preemption analysis undergone in DeCanas, emphasizing states' power to enact laws that are "fashioned to remedy local problems" and "operate[] only on local" actors. ${ }^{112}$

In his majority opinion, Justice Kennedy struck down all of these sections, except for Section 2(B), as preempted by federal law. The Court held that Section 3, the piece that criminalized failure to comply with federal alien registration requirements, was preempted on a field preemption theory and under Hines v. Davidowitz, and that Section 5(C), which criminalized the unauthorized seeking of employment, was preempted on an obstacle preemption theory. Both of these holdings tracked the usual logic of field and obstacle preemption. ${ }^{113}$ The Court

${ }^{109}$ Id. at 2498 (quoting Ariz. Rev. Stat. Ann. § 13-3883(A)(5) (2011)).

${ }^{110} \mathrm{Id}$.

${ }^{111}$ S.B. 1070, 49th Leg., 2d Reg. Sess. 11 (Ariz. 2010).

112 DeCanas v. Bica, 424 U.S. 351,363 (1976).

${ }^{113}$ See Arizona, 132 S. Ct. at 2501-05. The $\S 3$ holding appears to have been the easiest for the Court; even Justice Alito, who dissented with regard to some of the other sections, concurred. See id. at 2529-30 (Alito, J., concurring in part and dissenting in part). Section 5(C) was a closer call. Here, "there was no comprehensive federal program regulating the employment of unauthorized aliens" and the "State had authority to pass its own laws on the subject." Id. at 2503 (majority opinion). But Congress had passed IRCA, the Immigration Reform and Control Act of 1986, which imposes federal criminal and civil penalties on employers who hire unauthorized employees, but imposes only civil penalties on employees. IRCA, the Court explained, reflected "a considered judgment that making criminals out of aliens engaged in unauthorized work-aliens who already face the possibility of employer 
could have undertaken a similar preemption analysis had "immigration" not been the subject of the state law in question, based purely on Congress's extensive prior activity in alien registration and employee sanctions.

The Court's analysis of Section 6, the warrantless arrest provision, was quite different. Here, the Court found that allowing Arizona police officers to conduct warrantless arrests of individuals if there was probable cause to believe they had committed a public offense that made them deportable created an "obstacle" to federal enforcement, but why is unclear. Allowing state officers to arrest suspected unauthorized aliens would allow a state to "achieve its own immigration policy," the opinion stated, and this could lead to "unnecessary harassment of some aliens... whom federal officials determine should not be removed." 114 But it is not clear from the statute why state police officers were allowed to arrest; it is possible that Section 6 was not merely to harass individuals, but because Arizona wanted to make criminal aliens available to the federal government for deportation when it perceived the federal government to be too financially strapped to do this work itself. Arizona was litigated at the preliminary injunction stage, so the statute had not yet gone into effect. Whether the statute would have been applied by Arizona in a discriminatory way is difficult to know without a record of its enforcement.

According to Justice Kennedy's opinion, "Congress has put in place a system in which state officers may not make warrantless arrests of aliens based on possible removability except in specific, limited circumstances." 115 But the opinion does not analyze why that might be so. It suggests that these circumstances are set forth in 8 U.S.C. $\S 1357(\mathrm{~g})$, also known as INA $\S 287(\mathrm{~g})$. The argument seems to be that because Congress set forth a mechanism in Section $287(\mathrm{~g})$ for cooperation agreements between federal and state governments regarding immigration enforcement, anything falling outside these formal agreements is not "cooperation," but instead an obstacle to federal control. ${ }^{116}$ The opinion then further distinguishes Section $287(\mathrm{~g})(10)$, which reads that nothing in the statute prohibits state officers from "cooperat[ing] with the Attorney

exploitation because of their removable status-would be inconsistent with federal policy and objectives." Id. at 2504.

${ }^{114}$ Id. at 2506.

${ }^{115}$ Id. at 2507.

${ }^{116} \mathrm{Id}$. 
General in the identification, apprehension, detention, or removal of aliens not lawfully present in the United States," as precluding state officials from ever making a decision to arrest an alien for being removable "absent any request, approval, or other instruction from the Federal Government"-in other words, in order to "cooperate," the federal government must initiate the interchange. ${ }^{117}$ Justice Kennedy may well be right about his interpretation of Section $287(\mathrm{~g})$, but the discussion in the opinion does a poor job of justifying it. There is no reference to the legislative history of the statute or alternative readings. And there is no explanation of why, even if Kennedy's reading is right, Section 6 would be preempted by federal law, or why a dual system of arresting suspected unauthorized immigrants would create an obstacle to federal enforcement. Again, there may be good reasons why an obstacle exists, but they are not in the opinion. ${ }^{118}$

Instead, the majority opinion tells us that "[b]y authorizing state officers to decide whether an alien should be detained for being removable, Section 6 violates the principle that the removal process is entrusted to the discretion of the Federal Government." ${ }^{\prime 19}$ The opinion then states that decisions on removability "require[] a determination whether it is appropriate to allow a foreign national to continue living in the United States" and that those decisions "touch on foreign relations and must be made with one voice." ${ }^{\prime 20}$ But Arizona does not appear to have been trying to remove anyone, at least not by its own volition. S.B. 1070 did not purport to grant Arizona police officers the power to deport unauthorized aliens, just to arrest them (presumably so that Immigration and Customs Enforcement ("ICE") could deport them if it so chose). The move the Court makes from arrest to deportation is a rhetorical sleight-of-hand that tracks the doctrinal move it is making from alienage to immigration, from conflict preemption to plenary power preemption. It allows the majority to strike down Section 6 while avoiding a full-blown conflict preemption analysis.

\footnotetext{
${ }^{117}$ Id.
}

${ }^{118}$ See, e.g., Amici Curiae Brief of Members of Congress in Support of Respondent at 1619, Arizona, 132 S. Ct. 2492 (2012) (No. 11-182) (arguing that $\S 6$ "pose[s] an obstacle to the full execution and accomplishment of federal objectives" and outlining federal objectives).

${ }^{119}$ Arizona, 132 S. Ct. at 2506.

${ }^{120}$ Id. at 2506-07. 
Similarly, Justice Kennedy's opinion provisionally upheld the socalled "centerpiece" or "heart" of S.B. 1070 - the "papers please" provision, by which "officers who conduct a stop, detention, or arrest must in some circumstances make efforts to verify the person's immigration status with the Federal Government." ${ }^{212}$ Here, the majority declined to strike down the law, but did so in a way that makes it unlikely to be very useful as a law enforcement tool. If the police do not unnecessarily detain a suspected "illegal alien," the Court suggests, then there may be no constitutional problem. The opinion gives two hypotheticals. In the first, a jaywalker is stopped and is unable to produce identification; in the second, a drunk driver is arrested and taken into custody. ${ }^{122}$ In the jaywalking case, a state court could interpret Section 2(B) to mean that it would not be "reasonable to prolong the stop for the immigration inquiry," unless "the person continues to be suspected of some crime for which he may be detained." ${ }^{23}$ In the drunk driving hypothetical, where the person is arrested and not merely stopped, Section 2(B) states that law enforcement "shall have the person's immigration status determined before [he] is released." 124 This brief detention might be constitutional, the majority opinion offers, if state courts interpret "determined" to mean initiating but not completing a check, or if the check can be completed without a "prolonged detention." 25

So the "papers please" provision might be constitutional if it is interpreted as (1) simply asking for papers and (2) checking identity quickly without any unnecessary detention. In cases where identity cannot be proven quickly (for instance, a U.S. citizen traveling without identification or a noncitizen who has applied for lawful status but is waiting for a response from federal authorities), the state has an interest in ultimately getting the information but no interest in detaining the person while that information is sought. And what is Arizona supposed to do with the information once it has it? Section 6 is unconstitutional-an officer does not have probable cause to arrest the noncitizen simply because the of-

${ }^{121}$ Id. at 2498; see also Adam Liptak, Court Splits Immigration Law Verdicts; Upholds Hotly Debated Centerpiece, 8-0, N.Y. Times, June 26, 2012, at A1 (citing Governor Jan Brewer of Arizona as saying "she welcomed the decision to uphold what she called the heart of the law").

${ }_{122}$ Arizona, 132 S. Ct. at 2509.

${ }^{123}$ Id.

${ }^{124}$ Id. (quoting S.B. 1070, 49th Leg., 2d Reg. Sess. § 2(B) (Ariz. 2010) (alteration in original)).

${ }^{125} \mathrm{Id}$. 
ficer knows his or her status. All Arizona can do is let ICE officers know that the person exists.

In short, the majority draws a distinction between Section 6 and Section 2(B), by reading them, respectively, as implicating immigration and not implicating immigration. Section 6 is an "obstacle" to federal enforcement priorities and a stealthy mechanism by which the state seeks to "achieve its own immigration policy," because arrest is the first step to deportation. But Section 2(B) is just an inquiry into a person's status that the state can permissibly enter into so that it can helpfully let ICE know that someone is available for deportation. If Arizona enforces Section 2(B) differently, allowing inquiries into identity to effectively turn into arrests, then, like Section 6, it might be preempted. ${ }^{126}$ Thus, even though there is no preemption analysis regarding Section 2(B), it might be vulnerable under the same theory as Section $6 .{ }^{127}$

If this analysis were all there were to Justice Kennedy's opinion, we might worry that it gives very little notice to states about where the line between "achieving its own immigration policy" and simple helpfulness lies. Justice Kennedy's opinion, however, includes not only the preemption analyses summarized above, but also begins with a fairly long section outlining the federal and state interests at play in the immigration context. In order to engage in a preemption analysis, all the Court needed to do was establish a legitimate federal purpose in the area. Instead, the opinion goes to great lengths to show how broad and indisputable federal power is over immigration. ${ }^{128}$ This is so, the opinion explains, because "[i]mmigration policy can affect trade, investment, tourism, and diplomatic relations for the entire Nation," and because "[p]erceived

\footnotetext{
${ }^{126} \mathrm{Id}$.

${ }^{127}$ Several other sections of S.B. 1070 were not at issue in the Arizona case, either because they went unchallenged or because they were not enjoined by the court below and no appeal was taken. These included a prohibition on "sanctuary cities" in Arizona, S.B. 1070, 49th Leg., 2d Reg. Sess. § 2(A) (Ariz. 2010) (codified as amended at Ariz. Rev. Stat. Ann. § 111051(A) (2010)); a provision allowing legal residents to sue state officials for failing to fully enforce immigration law, S.B. $1070 \S 2(\mathrm{G})$ (codified as amended at $\S 11-1051(\mathrm{H})$ ); a provision enabling police officers to lawfully stop a motor vehicle if there is reasonable suspicion the person is in violation of a civil traffic law when the officer is enforcing human smuggling laws, S.B. $1070 \S 4$ (codified as amended at $\S 13-2319$ ); a provision that makes it a crime to stop in a motor vehicle to pick up day laborers, S.B. $1070 \S 5$ (codified as amended at $\S 13-$ 2928(A)); and a provision that criminalizes the transport or harbor of an unlawfully present alien or the encouraging of an unauthorized alien to come to Arizona, S.B. $1070 \S 5$ (codified as amended at $\S 13-2929)$.

${ }^{128} 132 \mathrm{~S}$. Ct. at $2498-500$.
} 
mistreatment of aliens in the United States may lead to harmful reciprocal treatment of American citizens abroad." 229 It then goes into great detail about how federal law regulates both admission of and removal of aliens, and the complex factors that go into making enforcement decisions. ${ }^{130}$

Justice Kennedy claims that "[t]hese concerns are the background for the formal legal analysis that follows," especially the analysis of Section 6 preemption and the potential asapplied preemption of Section 2(B)-is more than mere background. Rather, the analysis itself is dependent on the notion that immigration uniquely implicates foreign affairs. The logic goes something like this: The immigration power-meaning the power to regulate admission and removal of aliens - is exclusively federal. Section 6 authorizes Arizona to take the first step in removal of an alien by authorizing an arrest. Therefore, Section 6 is preempted, not because there is an actual conflict, but because the state has overstepped its bounds by attempting to legislate in an exclusively federal area. Although Section 2(B) is not preempted on its face, it is in danger of being preempted as applied, should Arizona choose to enforce it in a way that looks like the first step in removal.

In retrospect, perhaps the part of S.B. 1070 that should have tipped everyone off to its likely preemption was not one of the challenged sections, but Section 1, which set out the purpose of the statute. Section 1 could have set out a policy rooted in the state's police power, citing, for example, the statistics that Justice Kennedy cited in the majority opinion about an immigration-induced crime wave in Arizona. ${ }^{132}$ Instead, the legislature stated that "the intent of this act is to make attrition through enforcement the public policy of all state and local government agencies in Arizona." ${ }^{133}$ Lest readers fail to understand the meaning of "attrition," the section went on to explain that "[t]he provisions of this act are intended to work together to discourage and deter the unlawful entry and presence of aliens and economic activity by persons unlawfully present

\footnotetext{
${ }^{129}$ Id. at 2498.

${ }^{130}$ Id. at 2499-500.

${ }^{131}$ Id. at 2500.

${ }^{132}$ Id. (noting that in Maricopa County, unauthorized aliens comprise $8.9 \%$ of the population but are responsible for $21.8 \%$ of the felonies). This is the type of analysis invited by the Plyler majority. See Plyler v. Doe, 457 U.S. 202, 228-29 (2002).

${ }^{133}$ S.B. 1070, 49th Leg., 2d Reg. Sess. § 1 (Ariz. 2010).
} 
in the United States." ${ }^{134}$ This statement of intent cast a shadow over S.B. 1070, giving Arizona the appearance of overreach into "core" immigration law. It appeared to be attempting to do what Chy Lung and Henderson had prohibited-influencing the decision of noncitizens to come to a state or stay there, and thereby influencing admission and deportation policy. Read in the context of "plenary power preemption," this statement is threatening indeed.

Several Justices wrote dissents in Arizona, and Justice Scalia's in particular offers a fascinating reversal of the plenary power preemption analysis that I identified in Justice Kennedy's majority opinion. The feature of Scalia's dissent that has garnered the most media attention, and the criticism of judges, academics, and pundits, is his diatribe against the current Administration's recent exercise of prosecutorial discretion to avoid deportation of so-called "DREAMers"-children who were brought here illegally by their parents at a very young age. ${ }^{135}$ But more relevant to the question of preemption doctrine is the dissent's near mirror-image of the majority's use of plenary power preemption, with states playing the role of the sovereign. Just as the majority opinion begins with a paean to federal sovereignty before launching into its preemption analysis, Justice Scalia's opinion begins with a history lesson, one that begins before the Founding and ends in 1837 with Miln, the last Supreme Court case to give state police powers precedence over the federal commerce and immigration powers. ${ }^{136}$ This lesson excludes Chy Lung and Henderson, and instead couches an early plenary power case, Fong Yue Ting, as a federal analogue to state sovereignty. ${ }^{137}$ In this worldview, the federal sovereign and the state sovereigns are all equally sovereign, capable of self-defense and capable of regulating admission and deportation, as it is "their sovereign prerogative to do."138 There can be instances for Justice Scalia when federal immigration law would preempt state immigration law, but only where federal law expressly

\footnotetext{
${ }^{134} \mathrm{Id}$.

${ }^{135}$ See, e.g., Nina Totenberg, Even Scalia's Dissenting Opinions Get Major Scrutiny, NPR (July 16, 2012), http://www.npr.org/2012/07/16/156852889/even-scalia-s-dissenting-opin ions-get-major-scrutiny (quoting Judge Richard Posner as saying, "There were no citations to that part of Justice Scalia's opinion .... It gives that part of the opinion the air of a campaign speech.").

${ }_{136}$ Arizona, 132 S. Ct. at 2511-13 (Scalia, J., dissenting); Mayor of N.Y. v. Miln, 36 U.S. $102,141-43$ (1837).

${ }^{137}$ Arizona, 132 S. Ct. at 2514 (Scalia, J., dissenting).

${ }^{138} \mathrm{Id}$.
} 
prohibits state action or where the laws conflict. The first scenario does not exist here, he explains, because "there is no federal law prohibiting the States' sovereign power to exclude." 139 And there is no conflict here because Arizona is not purporting to exclude "those whom federal law would admit" or admit "those whom federal law would exclude.,"140

Justice Scalia keeps up the state sovereignty theme throughout the dissent. If the majority puts a thumb on the scale for the federal government in its preemption analysis because of the unique context of federal sovereignty over foreign affairs, Justice Scalia does exactly the opposite. For him, the thumb on the scale in a preemption case goes to the sovereign entity whose sovereignty is being threatened-and in the Arizona case, that is Arizona, not the U.S. government. "We are not talking here about a federal law prohibiting the States from regulating bubble-gum advertising, or even the construction of nuclear plants," the Justice reminds us. "We are talking about a federal law going to the core of state sovereignty: the power to exclude." ${ }^{\text {141 }}$ In Justice Scalia's view, it is not a problem if the Arizona law regulates immigration rather than immigrants, if its goal is "attrition through enforcement," because "Arizona is entitled to have its own immigration policy-including a more rigorous enforcement policy-so long as [it] does not conflict with federal law." ${ }^{142}$ His opinion seems unlikely to sway the other Justices-Justice Thomas and Justice Alito, who also wrote dissents, did not sign on-but it is important nonetheless because it brings into high relief the work that sovereignty does for the majority.

\section{Plenary Power PreEMPTION's EFfects}

So far, this Essay has argued that the Supreme Court deviates from its usual preemption doctrine in alienage cases, applying instead an analysis I have termed "plenary power preemption." Why might the Court have developed such a doctrine? It could be, of course, simple politics-some

\footnotetext{
${ }^{139} \mathrm{Id}$.

${ }^{140}$ Id. at 2515 .

${ }^{141}$ Id. at 2514 (emphasis in original). Contrast this statement with the majority opinion in Hines v. Davidowitz, the Pennsylvania Alien Registration Act case. There, we are told that there is a greater federal interest in an immigration case than in other instances of federal regulation: "[T]his legislation deals with the rights, liberties, and personal freedoms of human beings, and is in an entirely different category from state tax statutes or state pure food laws regulating the labels on cans." 312 U.S. 52, 68 (1941).

$142132 \mathrm{~S}$. Ct. at 2516-17 (Scalia, J., dissenting) (emphasis in original) (internal quotation marks omitted).
} 
Justices on the Court might prefer the federal government's position on immigration-related issues to that of particular states, and may seek to find a way for the federal government to retain control even where traditional preemption principles do not seem adequate. I think, however, that the doctrine may serve other purposes. In this Part, I will explore two effects the doctrine has that the Court might find useful: avoidance of an inquiry into the scope of executive immigration power, and substitution for an inadequate equal protection doctrine.

\section{A. Executive Power}

One effect of plenary power preemption on immigration jurisprudence more broadly is the carving out of a doctrinal space for deference to the executive branch. Here, the label "plenary power preemption" is particularly useful. The preemption doctrine itself asks primarily whether a state statute is in tension with congressional intent, pitting statute against statute. But much of immigration law is actually decided by the executive branch, at the agency level, through formal regulations, memoranda of understanding, and day-to-day informal prosecutorial discretion. Conflicts between state and federal government may not look like conflicts unless the enforcement context is taken into consideration; the state statute may conflict more with agency policy than it does with the text of the statute.

It is unclear, however, whether the Executive has independent power over immigration, and, if so, how extensive that power is. The extent of the Executive's power in foreign relations is in dispute; the case law is mixed, ${ }^{143}$ and scholars have recently argued both for and against a broad, independent executive foreign relations power. ${ }^{144}$ The immigration con-

${ }^{143}$ Compare United States v. Curtiss-Wright Exp. Corp., 299 U.S. 304, 311, 319-20, 329 (1936) (upholding the President's action against Curtiss-Wright for selling guns to Bolivia, stating that "[i]n this vast external realm, with its important, complicated, delicate and manifold problems, the President alone has the power to speak or listen as a representative of the nation," and recognizing "the very delicate, plenary and exclusive power of the President as the sole organ of the federal government in the field of international relations-a power which does not require as a basis for its exercise an act of Congress"), with Dames \& Moore v. Regan, 453 U.S. 654, 665-66, 680, 686-88 (1981) (upholding Executive Orders entered into by Presidents Carter and Reagan suspending American lawsuits against Iran during the Iran hostage crisis, because Congress, through the International Claims Settlement Act of 1949 , had created a procedure to implement settlement agreements and had therefore acquiesced to the conduct engaged in by the President).

${ }^{144}$ See, e.g., Curtis A. Bradley \& Martin S. Flaherty, Executive Power Essentialism and Foreign Affairs, 102 Mich. L. Rev. 545, 546-52 (2004) (arguing against an interpretation of 
text is no different. The early plenary power cases made no distinction between the legislative and executive branches, holding instead that power over immigration resides in the "political" branches of the government at the expense of the judicial branch. ${ }^{145}$ As Professors Adam Cox and Cristina Rodríguez have shown, the Supreme Court has never resolved the questions of the source and scope of executive immigration power. ${ }^{146}$ Some cases appear to recognize broad, independent executive power over "core" immigration functions, such as which immigrants to lawfully admit. ${ }^{147}$ Others take a more limited view, treating immigration as a political issue, but giving Congress exclusive authority over the "formulation of ... policies." 148 The Court's reluctance to unequivocally decide that the immigration power rests solely in Congress may reflect a concern that the Executive needs room for ample enforcement discretion, as well as the ability to respond nimbly to international crises.

The reality of executive involvement in immigration, coupled with the Court's reluctance to define the source and scope of the Executive's power, may go far towards explaining the work that plenary power preemption does in cases such as Arizona. Consider, for example, the warrantless arrests that were struck down in Section 6 of S.B. 1070. At first glance, these arrests seem like they might be well within a state's traditional police powers, and, since they use congressionally-mandated categories of illegality as the basis for arrest, they do not seem to be in conflict with federal law. If we consider, however, that the Department of Homeland Security is in a position to make substantial official and unofficial policy about enforcement priorities, it is less clear that no conflict exists. This appears to have been the Arizona majority's concern when stating that " $[\mathrm{b}] \mathrm{y}$ authorizing state officers to decide whether an alien should be detained for being removable, Section 6 violates the principle that the removal process is entrusted to the discretion of the

Article II's Vesting Clause that grants broad power to the President); Saikrishna B. Prakash \& Michael D. Ramsey, The Executive Power over Foreign Affairs, 111 Yale L.J. 231, 252 -53, 256-57 (2001) (arguing that Article Il's Vesting Clause delegates primary foreign relations authority to the President).

${ }^{145}$ See, e.g., Chae Chan Ping v. United States, 130 U.S. 581, 609 (1889) (specifying that the "political department[s]" determine immigration matters).

${ }^{146}$ Cox \& Rodríguez, supra note 13 , at $472-83$.

${ }^{147}$ Knauff v. Shaughnessy, 338 U.S. 537, 542 (1950) (holding that " $[t]$ he right to [exclude aliens] stems not alone from legislative power but is inherent in the executive power to control the foreign affairs of the nation"); Cox \& Rodríguez, supra note 13, at 474-76.

${ }^{148}$ Galvan v. Press, 347 U.S. 522, 531 (1954). 
Federal Government." ${ }^{499}$ The federal government (read: the Executive) may have decided, for example, not to remove non-criminal aliens, because when resources are limited, it makes more sense to focus on violent offenders. ${ }^{150}$ Looking only to the federal and state statutes would underemphasize the importance of discretion at the agency level, discretion that Congress may wish agencies to have, but also discretion that may have its own independent basis in the plenary power doctrine.

\section{B. Equal Protection}

Plenary power preemption may be serving another important function, by filling a gap in equal protection doctrine. Immigrants, particularly undocumented immigrants, do not fit well within equal protection jurisprudence. Early cases suggested that noncitizens as a class would receive heightened scrutiny when bringing constitutional claims, so long as the government allegedly discriminating against them is not the federal government. ${ }^{151}$ But in Plyler v. Doe, the Court held that unauthorized aliens are not entitled to strict scrutiny because they are not members of a suspect class; their membership in the class is "the product of voluntary action" and "entry into the class is itself a crime."152 Instead, Plyler struck down the Texas statute denying undocumented children access to $\mathrm{K}-12$ education, ostensibly for failing to satisfy rational basis scrutiny, ${ }^{153}$ but based on reasoning that led the dissent to characterize the Court's opinion as classifying education as a quasi-fundamental

${ }^{149}$ Arizona, $132 \mathrm{~S}$. Ct. at 2506 . Indeed, this was the argument made in the amici brief by former Commissioners of the INS, who emphasized that "[i]mmigration enforcement... depends on the flexibility and ... adaptation ... to infinitely variable conditions." Brief of Former Commissioners of the United States Immigration and Naturalization Service as Amici Curiae in Support of Respondent at 5-6, Arizona, 132 S. Ct. 2492 (No. 11-182), 2012 WL 1044362 , at *5-6 (internal quotation marks omitted).

${ }^{150}$ See Memorandum from John Morton, Dir. of U.S. Immigration \& Customs Enforcement (June 17, 2011), available at http://www.ice.gov/doclib/secure-communities/pdf/ prosecutorial-discretion-memo.pdf (outlining prosecutorial discretion policy for ICE).

${ }^{151}$ See, e.g., Mathews v. Diaz, 426 U.S. 67, 84-85 (1976) (under plenary power doctrine, federal government may discriminate against aliens even where state governments may not); Graham v. Richardson, 403 U.S. 365, 372 (1971) ("Aliens as a class are a prime example of a 'discrete and insular' minority for whom such heightened judicial solicitude is appropriate.").

${ }^{152} 457$ U.S. 202, 219 n. 19 (1982).

${ }^{153}$ Id. at 224, 230. 
right $^{154}$ - a theory in tension with the Court's refusal to enforce this right in San Antonio Independent School District v. Rodriguez. ${ }^{155}$

Despite the schoolchildren's victory in Plyler, it is far from clear that equal protection challenges would defeat other anti-immigrant legislation. To be sure, the Eleventh Circuit recently invoked Plyler in striking down a piece of Alabama's anti-immigrant statute, a provision that required schoolchildren to show either a birth certificate or lawful immigrant status, or go on record as being an unauthorized alien. ${ }^{156}$ This holding, however, seems uniquely limited to the public school primary and secondary education context. Indeed, as the Eleventh Circuit panel emphasized, the Plyler Court's language relied on the "blamelessness" of children and the "fundamental role" of education in "maintaining the fabric of our society." 157 In contrast, much of the new state legislation authorizes the police to stop or arrest individuals suspected of unlawful presence-people who may not be "blameless." And although these statutes may result in the detention of lawful immigrants and U.S. citizens, and may disproportionately affect people of color, non-English speakers, or anyone else who appears to a police officer to be an unauthorized immigrant, racial profiling claims are notoriously difficult to prove. ${ }^{158}$ An equal protection claim requires proof of discriminatory intent, something that is difficult to show in the arrest context.

Preemption doctrine may help fill this gap. Preemption claims do not require a demonstration of discriminatory intent, but there is room for judges to consider the possibility of discrimination when they evaluate whether the federal government has different legislative or enforcement goals than a state may have. In fact, as Professor Hiroshi Motomura has argued, evidence of discrimination may actually bolster preemption claims in some cases. ${ }^{159}$ Professor Motomura also suggests that preemp-

\footnotetext{
${ }^{154}$ Id. at 244 (Burger, C.J., dissenting).

${ }^{155}$ Compare id. at 224, 230, with San Antonio Indep. Sch. Dist. v. Rodriguez, 411 U.S. 1, 35-37 (1973).

${ }^{156}$ Hispanic Interest Coal. of Ala. v. Alabama, 691 F.3d 1236, 1244, 1249 (11th Cir. 2012).

${ }_{157}^{15}$ Id. at 1245-46 (internal quotation marks omitted).

${ }^{158}$ See Brandon Garrett, Remedying Racial Profiling, 33 Colum. Hum. Rts. L. Rev. 41, $61-81(2001)$.

${ }^{159}$ Hiroshi Motomura, The Rights of Others: Legal Claims and Immigration Outside the Law, 59 Duke L.J. 1723, 1734, 1741, 1743 (2010) (speculating whether the judge in Lozano v. City of Hazleton, 496 F. Supp. 2 d 477 (M.D. Pa. 2007)-where the court invalidated an ordinance barring the employment or harboring of unauthorized migrants - would have
} 
tion may slow down the political process and make constitutionally problematic immigration law less likely; if anti-immigrant forces must convince an entire nation to enact discriminatory laws, much of this type of legislation "might never be adopted."160

Plenary power preemption, then, while surely not the most straightforward of Supreme Court doctrines, may be doing important work. Without it, the Court would generally be in the position of applying a pure conflict preemption test to state statutes, and these statutes would often not appear to conflict with the text of federal legislation, yet they might interfere tremendously with federal enforcement goals. The Court may want to sidestep the question of the Executive's independent enforcement authority. Additionally, the doctrine may preserve a space for adjudicating claims that are unlikely to be brought successfully by unauthorized immigrants or citizens who are victims of racial profiling or other forms of discrimination.

\section{CONCLUSION}

This Essay has explored the opinions in the Arizona case and located them within a broader framework of preemption doctrine. I have argued that the Court often engages in an unusual form of preemption analysis-what I refer to as "plenary power preemption"-in the alienage context, and that it hides imprecise conflict preemption analysis behind this framework.

Two issues are worth considering going forward. First, plenary power preemption may be unsustainable as a doctrine. As Professor Juliet Stumpf has shown, in the last twenty-five years the federal government has expanded "immigration law into areas peculiarly of state and local concern, namely, criminal law, employment, and welfare"-what Professor Stumpf calls the "domestication of immigration law." 161 For example, the Personal Responsibility and Work Opportunity Reconciliation Act of 1996 devolved federal power to the states to deny benefits to certain immigrants. ${ }^{162}$ Similarly, the REAL ID Act prohibits some federal agencies from accepting state-issued driver's licenses unless a state

found the ordinance preempted if the plaintiffs had not introduced "so much evidence on race and ethnicity" in their attempt to make an equal protection claim).

${ }^{160}$ Id. at $1744-45$.

${ }^{161}$ Stumpf, supra note 12 , at 1582 .

1628 U.S.C. $\S \S 1622,1641$ (2006). 
has verified the person's immigration status. ${ }^{163}$ Given this new federal intrusion, Professor Stumpf suggests, "state forays into [the] governance of noncitizens have followed naturally." 164 Plenary power preemption can temporarily stave off state attempts to enforce federal immigration law, but there may be increasing pressure on Congress to state with greater specificity the role it wishes states to play. INA Section $287(\mathrm{~g})(10)$ - the "catch-all" provision of the federal-state cooperation statute at issue in Arizona-seems ripe for amendment if and when comprehensive immigration reform is enacted.

There is also the question of whether plenary power preemption is an example of "immigration exceptionalism" or whether it is in line with trends in the Court's preemption doctrine at large. The argument I have made here, establishing plenary power preemption as a unique doctrinal move, could support either view. By exposing the plenary-power infused preemption analysis engaged in by the Court, I have shown why immigration cases sometimes deviate from what one might expect from the application of conflict preemption doctrine. This insight indicates that something special is going on in alienage cases such as Arizona. By the same token, however, the conflict preemption doctrine itself leaves ample room for courts to engage in their own interpretations of what Congress really wants and what the federal government's purposes really are. Indeed, it is this aspect of the doctrine that has been most sharply critiqued by various scholars. ${ }^{165}$ Perhaps, "plenary power preemption" is simply yet another example of the malleable character of obstacle preemption in all of its forms.

\footnotetext{
${ }^{163}$ REAL ID Act of 2005,49 U.S.C. $\$ 30301$ (2006).

${ }^{164}$ Stumpf, supra note 12 , at 1582.

${ }^{165}$ See, e.g., Viet D. Dinh, Reassessing the Law of Preemption, 88 Geo. L.J. 2085, 2085 (2000) (stating that "[n]otwithstanding its repeated claims to the contrary, the Supreme Court's numerous preemption cases follow no predictable jurisprudential or analytical pattern"); Nelson, supra note 11, at 231, 304 (concluding, based on a historical reading of the Supremacy Clause, that "the modern doctrine of 'obstacle' preemption has no place as a doctrine of constitutional law").
} 